\title{
Infliximab treatment for Crohn's disease
}

\author{
C A Conroy, R Cattell
}

\section{Background}

Crohn's disease is a lifelong inflammatory disorder characterised by the presence of inflammatory ulcerative lesions in the gastrointestinal tract. ${ }^{1}$ Lesions most commonly involve the large and small bowel, giving rise to symptoms of abdominal pain, weight loss, gastrointestinal haemorrhage, and fistula formation. ${ }^{2}$ The disease may present at any age, however the second and third decades of life represent the peak ages of diagnosis. ${ }^{3}$ Although the pathophysiology of Crohn's disease is unknown, a number of possible aetiologies have been reported. These include the interaction of environmental, ${ }^{45}$ infectious, ${ }^{6-8}$ genetic, ${ }^{910}$ or immunological ${ }^{3}$ factors. To date, treatment has been geared towards symptomatic relief of disease exacerbations via pharmacological interventions such as aminosalicylates, corticosteroids, immunosuppressive agents, antibiotics, and nutritional therapy. Surgery is indicated in those patients who have failed to respond to medical management, or to correct intestinal obstruction or abscesses. This can be up to $50 \%$ of sufferers. ${ }^{1}$ Surgical intervention is by no means curative, with inflammatory episodes recurring in $\geqslant 80 \%$ of patients after intestinal resection. ${ }^{11}$

The advent of a therapy that can potentially restore immunological imbalance, modify the disease, and prolong remission in Crohn's disease patients, has thus been eagerly awaited.

\section{Cytokine targeted treatment}

The inflammatory response in Crohn's disease is regulated by intercellular mediators known as cytokines. ${ }^{12}$ The major contributing factor to chronic local inflammation in Crohn's disease is local mucosal overproduction of proinflammatory cytokines to anti-inflammatory cytokines. ${ }^{13}$ Tumour necrosis factor- $\alpha(\mathrm{TNF}-\alpha)$ is one of several proinflammatory mediators, which has a central role in chronic inflammatory conditions, such as Crohn's disease, rheumatoid arthritis, and other granulomatous diseases. There are currently two anti-TNF antibodies under clinical evaluation, infliximab and CDP571. ${ }^{14}$ Infliximab (Remicade, Schering Plough, UK) is a chimeric monoclonal antibody to $\mathrm{TNF}-\alpha$, developed as a therapeutic agent for TNF- $\alpha$ mediated diseases. Infliximab acts by binding and neutralising TNF, high levels of which are found in the mucosa of Crohn's disease sufferers, and thus rendering it biologically inactive. ${ }^{15}$

Following approval the Food and Drug Administration in 1998, a number of international working group recommendations were published limiting its administration (box 1). ${ }^{16}$

In 1999, infliximab became available on the UK market for treatment of severe active or fistulising Crohn's disease, where patients had inadequate response to conventional treatments. Although more expensive than current Crohn's disease treatment regimens, it has been suggested that fewer hospitalisations and surgical procedures (which account for $80 \%$ of Crohn's disease resource use and care expenditure), may result from infliximab infusion, and hence potentially induce cost savings to healthcare systems. The latter is, however, wholly dependent on the annual number of infusions each patient requires when/if a patient relapses. Hay and Hay demonstrated that if a new treatment modality was developed that doubled drug costs, but led to a $20 \%$ reduction in medical costs, the annual expenditure associated with Crohn's disease would decrease by $13 \% .{ }^{17}$ Although in the USA it remains to be established whether infliximab treatment results in a $20 \%$ reduction in medical costs, the savings incurred are moving in a positive direction. ${ }^{18}$

The recommended dose is $5 \mathrm{mg} / \mathrm{kg}$ body weight, but currently no standard guidelines exist as to the number of repeat infliximab administrations, or dosing interval between infusions, if relapse occurs. In the treatment of fistulae, however, repeat infusions are indicated if required, every 14 weeks. Work by Present and colleagues forms the clinical basis of working group recommendations of a total of three infusions in fistulising Crohn's disease. ${ }^{19}$

\section{Clinical studies}

The effect of infliximab on Crohn's disease management requires consideration of not only the acquisition cost, but also its impact on clinical outcome measures and safety. To date, 771 patients have received therapy with infliximab in clinical trials for the treatment of Crohn's disease, rheumatoid arthritis, or HIV infection (Schering-Plough Ltd, UK, personal correspondence, August 2000).

A summary of the pivotal studies in Crohn's disease patients is documented in table 1 .

\section{HISTOLOGICAL RESPONSE}

The effect of infliximab on histological abnormalities has been investigated in two studies (table 1). ${ }^{20}{ }^{21}$ Both trials concluded that infliximab induced profound down-regulation of the inflammatory mechanisms in the entire mucosal layer. Four weeks after infusion there were reductions in the Crohn's disease activity index (CDAI; this is discussed later) and Crohn's disease endoscopic index of severity scores, together with a decline in $\mathrm{C}$ reactive protein concentrations. ${ }^{21}$ Although both trials document a virtual disappearance of neutrophils, a conflict in findings with regards to infliximab's effect on mucosal architecture is evident in these studies. In the earlier of the two trials, the mucosal architecture returned to normal in four patients, ${ }^{20}$ whereas no patient in 


Box 1: Infliximab in Crohn's disease:
recommendations of an international
working group ${ }^{16}$
- Active disease: Steroids and
immunosuppressants should not be
eliminated as first line drugs in active
Crohn's disease.
- Recurrent disease: In recurrent responsive
disease, patients should receive steroid
monotherapy or combined treatment with
azathioprine. Infliximab should be reserved
for patients if (1) steroids are
contraindicated or (2) remission is not
achieved within four months of combined
treatment.
- Chronic active disease: In steroid
dependent chronic active disease,
azathioprine, and/or methotrexate are
recommended as first line treatment(s).
- Fistulae: Infliximab is indicated if surgery,
azathioprine, and/or antibiotic treatment
are unsuccessful in fistulising disease.

the trial by D'Haens and coworkers obtained normal mucosal architecture, four weeks after infusion. Larger anti-TNF- $\alpha$ trials, which examine not only the histological and endoscopic response, but also the effect of repeat infusion on these outcomes, could prove useful in defining the antibody's precise mode of action.

FISTULA CLOSURE

The literature currently available documents no evident correlation between side effects and
Table 2 Percentage of patients reaching primary and secondary endpoints after treatment with infliximab or placebo $^{19}$

\begin{tabular}{llll}
\hline & & \multicolumn{2}{l}{ Infliximab } \\
\cline { 3 - 4 } & Placebo & $5 \mathrm{mg} / \mathrm{kg}$ & $10 \mathrm{mg} / \mathrm{kg}$ \\
\hline Primary endpoint & 26 & 68 & 56 \\
$\quad$ p Value & - & 0.002 & 0.02 \\
Secondary endpoint & 13 & 55 & 38 \\
p Value & - & 0.001 & 0.04 \\
\hline
\end{tabular}

Primary endpoint: defined as $\geqslant 50 \%$ reduction in the number of draining fistulae from baseline observed on at least two consecutive visits (21 days apart).

Secondary endpoint: defined as closure of all fistulae on at least two consecutive visits (21 days apart).

repeat infusion, and that no dose response exists. The largest of the published findings conducted in patients with draining abdominal or perianal fistulae of at least three months' duration, clearly demonstrates this. ${ }^{19}$ Present and colleagues defined the primary endpoint in their study as at least a $50 \%$ reduction in the number of draining fistulae from baseline observed on at least two consecutive visits (21 days apart). Closure of all fistulae on at least two consecutive visits represented the secondary endpoint. The favourable clinical responses associated with the lower dose of infliximab are significant (table 2), particularly when one considers that anal complications such as fissures, fistula or abscess formation develop in $15 \%$ of patients with Crohn's disease within five years of diagnosis. ${ }^{22}$

The population recruited for this particular study included patients who had been receiving, and were maintained on, stable doses of immunosuppresants such as azathioprine/ mercaptopurine $(40 \%)$, corticosteroids (35\%), and aminosalicylates $(55 \%) .{ }^{19}$ Although the

Table 1 Key findings of clinical studies involving the treatment of Crohn's disease (CD) with infliximab

\begin{tabular}{|c|c|c|c|c|}
\hline Reference & Design & Patient population & $\begin{array}{l}\text { Acceptable concurrent trial } \\
\text { medication }\end{array}$ & Findings \\
\hline $\begin{array}{l}\text { Targan et al, } \\
1997^{29}\end{array}$ & $\begin{array}{l}\text { Multicentre, placebo } \\
\text { controlled, double blind, } \\
\text { randomised } \\
\text { Infliximab } 5 \mathrm{mg} / \mathrm{kg}(\mathrm{n}=27)\end{array}$ & $\begin{array}{l}\text { Moderate-severe CD, with a } \\
\text { CDAI score between } \\
220-400\end{array}$ & $\begin{array}{l}\text { Stabilised doses of } \\
\text { mesalamine; oral } \\
\text { corticosteroids; } \\
\text { 6-mercaptopurine; } \\
\text { azathioprine }\end{array}$ & $\begin{array}{l}\text { CDAI } \geqslant 70 \text { point reduction occurred in } 81 \%(n=22) \\
\text { of patients with moderate-severe disease patients, } \\
\text { versus } 17 \% \text { in the placebo group }(n=14) . \text { Remission } \\
\text { at week } 4 \text { was evident in } 48 \% \text { of study patients } \\
\text { compared to } 4 \% \text { in the placebo group }\end{array}$ \\
\hline $\begin{array}{l}\text { Rutgeerts et al, } \\
1999^{28}\end{array}$ & $\begin{array}{l}\text { Placebo controlled, double } \\
\text { blind, randomised } \\
\text { Infliximab } 10 \mathrm{mg} / \mathrm{kg} \text { ( } \mathrm{n}=37 \text {, } \\
4 \text { infusions } 2 \text { months apart) }\end{array}$ & $\begin{array}{l}\text { Retreatment of patients }{ }^{29} \\
\text { with moderate-severe CD, } \\
\text { with a CDAI score between } \\
220-400\end{array}$ & $\begin{array}{l}\text { Stabilised doses of } \\
\text { mesalamine; oral } \\
\text { corticosteroids; } \\
\text { 6-mercaptopurine; } \\
\text { azathioprine }\end{array}$ & $\begin{array}{l}\text { Infliximab gave a clinical response of } 62 \% \text { and } \\
\text { remission of } 52.9 \%, 8 \text { weeks after the last infusion } \\
\text { (week } 44 \text { ). This compares with a clinical response of } \\
37 \% \text { and remission of } 20 \% \text { at week } 44 \text { in the placebo } \\
\text { group }(n=36)\end{array}$ \\
\hline $\begin{array}{l}\text { Baert et al, } \\
\quad 1997^{20}\end{array}$ & $\begin{array}{l}\text { Multicentre, placebo } \\
\text { controlled, double blind, } \\
\text { randomised } \\
\text { Infliximab } 5 \mathrm{mg} / \mathrm{kg} \\
(\mathrm{n}=2), 10 \mathrm{mg} / \mathrm{kg}(\mathrm{n}=7), 20 \\
\mathrm{mg} / \mathrm{kg}(\mathrm{n}=4)(\text { as a single } \\
\text { infusion }) \text {, or placebo }(\mathrm{n}=5)\end{array}$ & Crohn's ileocolitis & $\begin{array}{l}\text { Stabilised doses of } \\
\text { sulfasalazine/mesalamine; } \\
\text { corticosteroids;antibiotics; } \\
\text { azathioprine }\end{array}$ & $\begin{array}{l}\text { Four weeks after infliximab resulted in a decrease in } \\
\text { the total histological activity score }(n=13) \text {, compared } \\
\text { with the placebo group }(n=5) \text {. In addition to the } \\
\text { reduction in histological disease activity, the mucosal } \\
\text { architecture of four patients returned to normal } 1 \\
\text { month after infusion }\end{array}$ \\
\hline $\begin{array}{l}\text { D'Haens et al, } \\
1999^{21}\end{array}$ & $\begin{array}{l}\text { Multicentre, placebo } \\
\text { controlled, double blind, } \\
\text { randomised } \\
\text { Infliximab } 5 \mathrm{mg} / \mathrm{kg}(\mathrm{n}=7) \text {, } \\
10 \mathrm{mg} / \mathrm{kg}(\mathrm{n}=7), 20 \mathrm{mg} / \mathrm{kg} \\
(\mathrm{n}=8)(\text { as a single infusion), } \\
\text { or placebo }(\mathrm{n}=8)\end{array}$ & $\begin{array}{l}\text { Active CD with a CDAI } \\
\text { score between } 220-400\end{array}$ & $\begin{array}{l}\text { Corticosteroids; } \\
\text { azathioprine }\end{array}$ & $\begin{array}{l}\text { Although inflammatory infiltrate disappeared in the } \\
\text { treatment group after } 4 \text { weeks, the architectural } \\
\text { abnormalities remained unchanged }\end{array}$ \\
\hline $\begin{array}{l}\text { Present et al, } \\
1999^{19}\end{array}$ & $\begin{array}{l}\text { Multicentre, placebo } \\
\text { controlled, double blind, } \\
\text { randomised } \\
\text { Infliximab } 5 \mathrm{mg} / \mathrm{kg}(\mathrm{n}=31) \text {, } \\
10 \mathrm{mg} / \mathrm{kg}(\mathrm{n}=32)(\text { at } 0,2, \\
\text { and } 6 \text { weeks), or placebo } \\
(\mathrm{n}=31)\end{array}$ & $\begin{array}{l}\text { Draining abdominal or } \\
\text { perianal fistulae of at least } 3 \\
\text { months' duration }\end{array}$ & $\begin{array}{l}\text { Stabilised doses of } \\
\text { aminosalicylates; } \\
\text { corticosteroids; } \\
\text { 6-mercaptopurine; } \\
\text { azathioprine }\end{array}$ & $\begin{array}{l}\text { Fistula closure was obtained in } 13 \% \text { of the placebo } \\
\text { population, } 55 \% \text { of those receiving } 5 \mathrm{mg} / \mathrm{kg} \\
\text { infliximab, and } 38 \% \text { of those receiving } 10 \mathrm{mg} / \mathrm{kg} \\
\text { infliximab } \\
\text { The median duration of fistula closure was } 3 \text { months } \\
\text { in the treatment groups }\end{array}$ \\
\hline
\end{tabular}

CDAI : Crohn's disease activity index. 
overall response to infliximab infusion was independent of current treatment with these agents, subgroup analysis demonstrated that patients receiving immunosuppressants did not obtain a significant benefit with active therapy compared with placebo $(59 \%$ v $44 \%$, respectively; $p=0.46) .{ }^{23}$ This would suggest that subgroup analysis of response to treatment is an important design feature to be considered in future trials.

\section{UNCONTROLLED STUDIES}

In an "audit" of the medical notes of seven patients (five females, two males) with medically refractory Crohn's disease (after ileal pouch anal anastamosis), clinical response was reported as complete in six patients, and partial in one patient. ${ }^{24}$ The trial participants received between one and four infliximab infusions at a dose of $5 \mathrm{mg} / \mathrm{kg}$. No relapses occurred in the six patients after a median observation period of 13.4 weeks. Complete response was defined as cessation of fistulae, drainage and total closure of all fistulae, or cessation of diarrhoea, incontinence, and abdominal pain. Partial response was defined as either a decrease in the number, size, drainage, or discomfort associated with fistulae, or a reduction in diarrhoea and abdominal pain. Although these case reports document the efficacy of infliximab in a different patient population, the lack of scientific rigour of this publication places minimal weight on the conclusions drawn. This is highlighted particularly when the dosing schedule is examined-that is, variable dosing interval between infusions, together with inconsistency in the number of infusions administered.

ASSESSING CLINICAL RESPONSE

A crucial aspect of evaluating the efficacy of any new treatment modality is the choice of outcome measure. All bar one study ${ }^{24}$ discussed so far include the CDAI as a quantitative means of assessing patient progress or decline. The CDAI is a validated and widely used scale (score values 0-600) which dictates disease remission at scores $<150$, or severe disease activity at values $>450 .{ }^{25}$ The CDAI incorporates eight related variables: the number of liquid/very soft stools per day; the severity of abdominal pain/cramping; general wellbeing; the presence or absence of extraintestinal manifestations of disease; the presence or absence of an abdominal mass; the use of antidiarrhoeal drugs; the packed cell volume, and body weight. Regulatory authorities recognise the CDAI as the "gold standard" for assessing pharmacological efficacy in Crohn's disease clinical studies. ${ }^{26}$ In addition, gastroenterologists in a large European study have reported its excellent correlation with clinical disease severity, when compared to another index. ${ }^{27}$

Laboratory tests, endoscopic biopsies, and quality of life measures represent additional means of confirming Crohn's disease activity. The test results obtained from these assessments are often used as secondary outcome markers, in adjunct to the CDAI.

\section{Clinical safety}

Of the 199 patients with Crohn's disease treated with infliximab in clinical studies (average follow up of 27 weeks), the most common adverse effects reported were headaches $(23 \%$ $v 21 \%$ with placebo), upper respiratory tract infection ( $16 \% v 9 \%$ with placebo), and nausea ( $17 \%$ v $4 \%$ with placebo).

LYMPHOPROLIFERATIVE EFFECTS?

In the retreatment of 37 patients with four additional doses of infliximab $(10 \mathrm{mg} / \mathrm{kg})$, one 61 year old man developed an intravascular duodenal B-cell lymphoma, 9.5 months after this infusion..$^{28}$ Although this patient was in the placebo arm of this trial, he had been previously treated with a single infusion of infliximab in the initial part of the trial (10 $\mathrm{mg} / \mathrm{kg}) .^{29}$ It is worth noting, however, that the patient had lymphopenia at baseline, and was receiving immunosuppressive therapy before infliximab administration.

Over 50000 Crohn's disease patients have received multiple or single infusions of infliximab, and there have been two cases of lymphoma reported in this particular patient population. It remains unclear whether the existence of Crohn's disease itself puts patients at risk for developing lymphoma, since observational studies have led to conflicting results. ${ }^{30-33}$ Two factors which would suggest an increased risk, include:

- Existence of a chronically activated and abnormal immune system. ${ }^{34}$

- Exposure to immunosuppressive therapies $^{35}$ and ionising radiation. ${ }^{34}$

Although the precise mechanism of infliximab therapy in Crohn's disease is not fully understood, the absence of associations with reduced absolute lymphocyte count, ${ }^{36}$ anergy development, ${ }^{37}$ or opportunistic viral and fungal infections, ${ }^{38}$ would suggest that TNF blockade with infliximab may lead to limited and selective immunosuppression, as opposed to broad spectrum immunosuppression. ${ }^{34}$ Nevertheless, since the safety of infliximab beyond its recommended duration of treatment remains to be established, tumour surveillance via physical examination is advisable at each visit after infusion. The international working group also proposes that abdominal ultrasound and chest radiography is performed on an annual basis to detect for the development of lymphoproliferative disorders. ${ }^{16}$

Hypersensitivity reactions, differing in time of onset have also been observed. The majority of patients experienced reactions during or within two hours of infusion, although a small number of cases were documented 3-12 days after infusion.

In addition, treatment with infliximab has led to antinuclear and anti-dsDNA antibody development in $34 \%$ and $9 \%$ of patients respectively, between screening and last study visit. Baseline therapy with an immunosuppressant was, however, associated with reduced anti-dsDNA antibody development. Development of anti-dsDNA antibodies had no relation with dose or duration of infliximab. In one 
patient, clinical signs consistent with a lupuslike syndrome were reported among infliximab treated trial participants. Improvement in symptoms was achieved by discontinuation of treatment and appropriate intervention (personal communication, Schering-Plough, UK).

It is worth noting that post-marketing adverse event data since product approval have been similar in type and occurrence in trial populations.

\section{Cost of prescribing}

In the UK alone, there are an estimated 30000 Crohn's disease sufferers, $4.7 \%$ of whom have severe active disease, and a further $2.3 \%$ who have developed fistulae. ${ }^{38}$ The actual cost of infliximab treatment is solely dependent on body weight and disease status - severe active requiring a single $5 \mathrm{mg} / \mathrm{kg}$ infusion, and fistulising patients requiring three such infusions at weeks 0,2 , and 6 . It can hence be estimated that the cost of treating this target population with infliximab will be in the region of $£ 1.575$ million, in the UK alone (cost of treatment is based on an average weight of 75 $\mathrm{kg}$ ). Since support groups for Crohn's disease sufferers, as with other patient groups, continue to apply pressure to healthcare teams for the introduction of new therapies among patients, it may be inevitable that this figure is an underestimation.

\section{Promising anti-TNF alternatives}

Although anti-TNF therapy has been cited to revolutionise the management of Crohn's disease, the current cost conscious healthcare environment will require the evaluation of alternative TNF inhibitors that prove to be less expensive without compromising clinical efficacy.

CDP571 (Celltech, Chiroscience, UK), which has a similar action to infliximab, is the second anti-TNF antibody to be clinically evaluated. Initial results in patients with moderate to severe Crohn's disease suggest a clinical effect beyond its half life. ${ }^{39}$

The TNF receptor/Fc fusion protein etanacept (Enbrel, Immunex, USA) has provided excellent clinical response in patients with rheumatoid arthritis. ${ }^{40}$ Preliminary investigations of its impact in Crohn's disease sufferers are underway. Thalidomide, which acts as an inhibitor in TNF production, has been assessed in a number of open label trials. ${ }^{41}{ }^{42}$ In 14 patients with a CDAI score $>200$ and/or draining perianal disease who completed 12 weeks of treatment with $200 \mathrm{mg}$ or $300 \mathrm{mg}$ thalidomide, clinical remission was achieved in nine. ${ }^{41}$ Lower doses were reported to be effective in a pilot study of 12 males with moderatesevere, steroid dependent Crohn's disease. Disease activity improved consistently during the first month of thalidomide treatment. When steroid doses were reduced at week 5 , clinical improvement was maintained up until trial completion (week 12). ${ }^{43}$

\section{Conclusion}

Through a greater understanding of the pathogenesis of Crohn's disease, anti-TNF- $\alpha$ antibody development has expanded the treatment options available for this debilitating condition. Although we are certain that good response is achieved in certain patient populations, the current published clinical data are incomplete. Establishing the long term efficacy and safety of infliximab, in addition to certain cost effectiveness issues, will become focal in future research. Firm guidelines relating to the use of infliximab in practice need to be established via outcome research. Infliximab administration is recommended in patients with fistulising or active Crohn's disease (defined as a CDAI score between 220-400), who have responded inadequately to conventional treatments. Extending its use outside this patient population should be prevented until good quality clinical studies dictate otherwise. The financial consequences of product use are dependent on the rate of relapse. The identification of an agent which could lengthen remission would be useful, hence reducing the requirement for repeat infliximab infusion in fistulising sufferers. Steroid sparing immunosuppressants such as azathioprine and 6-mercaptopurine represent investigative possibilities. The fact that the use of all immunosuppressants at baseline not only delays autoimmune response but also reduces infusion reactions, would suggest concurrent therapy to be beneficial. Coprescribing would, however, abolish any claims of infliximab inducing and maintaining disease remission in isolation. In those sufferers who do not respond to infliximab infusion, repeat administration will be of no additional benefit. ${ }^{14}$ Similar caution in prescribing should be observed in those patients who have antinuclear antibodies at baseline, as this subgroup are approximately twice as likely to develop anti-dsDNA antibodies.

Clinicians and patients have welcomed infliximab, when alternative pharmacological approaches have been exhausted. The concerns regarding the cost of prescribing may be short lived, since infliximab represents the first of a number of anti-TNF- $\alpha$ treatments under investigation, some of which may prove to be more economically viable options.

1 Hannauer SB, Meyers S. Management of Crohn's disease in adults. Am F Gastroenterol 1997;92:559-64.

2 Scott D, Saunders A. The differential diagniosis of Crohn's disease and ulcerative colitis. Balliere's Clin Gastroenterol 1998;12:19-33.

3 Crawford JM. The gastrointestinal tract. In: Cotran RS, Kumar V, Robbins SL, eds. Robbin's pathologic basis of disease. Philadelphia: WB Saunders, 1994: 801-6.

4 Podolsky DK. Inflammatory bowel disease. $N$ Engl f Med 1991;325:928-37.

5 Thomas GAO, Rhodes J, Green JT. Inflammatory bowel disease and smoking. Am $\mathcal{f}$ Gastroenterol 1998;93:144-9.

6 Elson CO, Sartor RB, Tennyson GAA, et al. Experimental models of inflammatory bowel disease. Gastroenerology 1995; 109:1344-67.

7 Van Kruiningen HJ. On the use of antibiotics in Crohn's disease. F Clin Gastroenterol 1995;20:310-16.

8 Sanderson JD, Moss MT, Tizard ML, et al. Mycobacterium paratuberculosis DNA in Crohn's disease tissue. Gut 1992; 33:890-6.

9 Ogorek CP, Fisher RS. Differentiation between Crohn's disease and ulcerative colitis. Med Clin North Am 1994;78: 1249-59.

10 Kornbluth A. Sachar DB, Salomon P. Crohn's disease. In: Feldman M, Scvharschmidt BF, Sleisenger MH, eds. Sleisenger and Fordtran's gastrointestinal and liver disease. 6 th Ed. Vol 2. Philadelphia: WB Saunders, 1998: 1709-17. 
11 Hanauer SB, Cohen RD, Becker RV, et al. Advances in the management of Crohn's disease: economic and clinical management of Crohn's disease: economic and

12 Sartor RB. Cytokines in intestinal infalmmation: pathophysiological and clinical considerations. Gastroenterology 1994;106:533-9.

13 Rogler G, Andus T. Cytokines in inflammatory bowel disease. World 7 Surg 1998;22:382-9.

14 Bell S, Kamm MA. Anti-TNF-alpha antibody treatment for Crohn's disease. Research and Clinical Forums 2000;22:12935 .

15 Knight DM, Trinh H, Le J, et al. Construction and initial characterisation of a mouse-human anti-TNF antibody. Mol Immunol 1993;30:1443-53.

16 Lochs $\mathrm{H}$, Alder G, Beglinger $\mathrm{CH}$, et al. Anti-TNF antibody in Crohn's disease-status of information, comments and recommendations of an international working group. $Z$ Gastroenterol 1999;37:509-12.

17 Hay AR, Hay JW. Inflammatory bowel disease: medical cost algorithims. F Clin Gastroenterol 1992;14:318-27.

$18 \mathrm{Mc}$ Clellan K. Cytokine-targetted therapies cost-effective in Crohn's disease? Pharmacoeconomics 1999;1174:6-7.

19 Present DH, Rutgeerts P, Targan S, et al. Infliximab for the treatment of fistulas in patients with Crohn's disease. $N$ Engl f Med 1999;340:1398-405.

20 Baert FJ, D'Haens G, Peeters M, et al. Tumour necrosis factor $\alpha$ antibody (infliximab) therapy profoundly downregulates the inflammation of Crohn's ileocolitis. Gastroenterology 1999;116:22-8.

21 D'Haens G, Van Deventer S, Van Hogezand R, et al. Endoscopic and histological healing with infliximab anti-tumour necrosis factor antibodies in Crohn's disease: a European multicentre trial. Gastroenterology 1999;116:1029-34.

22 Williams D, Coller J, Corman M, et al. Anal complication in Crohn's disease. Dis Colon Rectum 1981;24:22-4.

23 Lofberg R. Treatment of fistulas in Crohn's disease with infliximab. Gut 1999;45:642-3.

24 Ricart E, Panaccione R, Loftus EV, et al. Successful management of Crohn's disease of the ileoanal pouch with infliximab. Gastroenterology 1999;117:429-32.

25 Gregor JC, McDonald JWD, Klar N, et al. An evaluation of utility measurement in Crohn's disaese. Inflammatory Bowel Disease 1997;3:265-76.

26 Hanauer SB. Inflammatory bowel disease. $N$ Engl f Med 1996;334:841-7.

27 Goeball $\mathrm{H}$, Wienbeck M, Schomerus $\mathrm{H}$, et al. Evaluation of the Crohn's disease activity index (CDAI) and the dutch index for severity and activity of Crohn's disease. An analysis of the data from the european cooperative Crohn's disease study. Med Klin 1990; 85: 573-6.
28 Rutgeerts P, D'Haens G, Targan S, et al. Efficacy and safety of retreatment with anti-tumour necrosis factor antibody (infliximab) to maintain remis
troenterology 1999;117:761-9.

29 Targan SR, Hanauer SB, van Deventer SJH, et al. A short-term study of chimeric monoclonal antibody $\mathrm{Ca} 2$ to tumour necrosis factor $\alpha$ for Crohn's disease. $N$ Engl f Med 1997;337:1029-35

30 Loftus EV, Sandborn WJ, Tremaine WJ, et al. Risk of lymphoma in inflammatory bowel disease; a population based estimate. Gastroenterology 1998;114:A1024.

31 Bernstein CN, Kiliewer E, Rawsthorne P, et al. Diagnoses of extra-intestinal manifestations and cancers in IBD in large population-based databases. Gastroenterology 1998;114:A930.

32 Ekbom A, Helmick C, Zack M, et al. Extracolonic malignancies in inflammatory bowel disease. Cancer 1991;

33 Present DH, Meltzer SJ, Krumholz MP, et al. 6-Mercaptopurine in the management of inflammatory bowel disease: short- and long-term toxicity. Ann Intern Med 1989;111:641-9.

34 Bickston SJ, Lichtenstein GR, Kristen O, et al. The relationship between infliximab treatment and lymphoma in Crohn's disease. Gastroenterology 1999;117:1433-7.

35 Farrell RJ, Ang Y, Kileen P, et al. Increased incidence of non-Hodgkin's lymphoma in inflammatory bowel disease patients on immunosuppressive therapy but overall risk is low. Gut 2000;47:514-9.

36 Meenan J, Hommes DW, van Dulleman H, et al. The influence of TNF $\mathrm{mAB}$ cA2, on circulating lympohocte populations. Gastroenterology 1997;122:A1039.

37 Feldmann M, Elliott MJ, Woody J, et al. Anti-tumor necrosis factor alpha therapy of RA. Adv Immunol 1997;64:283350

38 British Society of Gastroenterology. Inflammatory bowel disease guidelines. London: BSG, 1996.

39 Sandborn WJ, Targan S, Wolf SB, et al. Randomised, double-blind, placebo-controlled, multi-centre trial of the double-blind, placebo-controlled, multi-centre trial of the
engineered human antibody to TNF (CDP571) for the induction and maintenance of clinical improvement in induction and maintenance of clinical improvement in putients with moderat

40 Moreland LW, Schiff MH, Baumgartner SW, et al Etanercept therapy in rheumatoid arthritis. A randomised controlled trial. Ann Intern Med 1999;130:478-86.

41 Ehrenpreis ED, Kane SV, Cohen SB, et al. Thalidomide therapy for patients with refractory Crohn's disaese: an open-label trial. Gastroenterology 1999;117:1271-7.

42 Vasiliauskas EA, Kam LY, Abreu-Martin MT, et al. An open-label pilot study of low-dose thalidomide in chronically active, steroid-dependent Crohn's disease. Gastroenterology 1999;117:1278-87. 